\title{
Children's preferences for gender-typed objects and colours: a commentary from gender research in Spain
}

\section{Las preferencias de niños y niñas hacia objetos y colores tipificados por género: un comentario desde la investigación de género en España}

\author{
Raúl Navarro \\ Universidad de Castilla-La Mancha, España \\ Disponible online 31 de diciembre de 2014
}

\begin{abstract}
The main aim of this review was to examine international research on children's preferences regarding gender-typed objects and colours. Firstly, we provide the theoretical background on gender development to elucidate the ways in which individuals can learn gender stereotypes and develop gender-related preferences. Secondly, we review international research on gender-related preferences. Thirdly, we analyse empirical studies on gender stereotypes in children conducted in Spain and Latin American countries, and show that although gender is a priority research area in these countries, studies on gender development in childhood are lacking. Thus, our aim was to identify a set of issues that provide insights into the development of gender-typed preferences, and that also suggest new directions for researchers in Spanish-speaking countries who are interested in clarifying the relationship between gender and children's preferences for objects and colours.
\end{abstract}

Key words: Gender; Children; Gender-typed Toys; Gender-typed Colors; Gender-typed Preferences.

El principal objetivo de esta revisión es examinar la investigación internacional sobre las preferencias de niños y niñas acerca de los objetos y colores tipificados por género. En primer lugar, ofrecemos un repaso sobre dos de las teorías más importantes sobre el desarrollo del género con el objetivo de dilucidar el modo en que las personas pueden aprender estereotipos de género y desarrollar preferencias tipificadas para su género. En segundo lugar, revisamos la investigación internacional sobre estas preferencias. En tercer lugar, examinamos la investigación que sobre los estereotipos de género se ha realizado en España y en países Latino Americanos. Analizamos que, aunque el género es un área prioritaria de la investigación en estos países, los estudios sobre el desarrollo del género en la infancia son menos numerosos. De ahí que nuestro objetivo sea el de señalar aspectos clave en el estudio del desarrollo de las preferencias tipificadas por género que puedan servir como sugerencias para los investigadores en países de habla hispana interesados en clarificar la relación entre el género y las preferencias de niños y niñas hacia los objetos y los colores.

Palabras clave: Género; Niños, Niñas; Juguetes Tipificados por Género; Colores Tipificados por Género; Preferencias Tipificadas por Género.

Correspondence concerning this article should be addressed to: Raúl Navarro. Departamento de Psicología. Universidad de Castilla-La Mancha. Facultad de Educación y Humanidades. Avda de los Alfares, 42. 16071. Cuenca. España. E-mail: Raul.Navarro@uclm.es 
"Dolls are for girls and trucks are for boys" and "blue is for boys and pink is for girls" are commonly accepted beliefs in the activities, objects and colors that differentiate girls from boys. These stereotypes form part of the gender social category, which is defined as a set of shared beliefs within a culture about attributes that men and women should have (Moya, 1996). In this way, gender is considered a social construct, and not just a product of our biology (Matud, 2004). For a long time now, such cultural beliefs have been studied as widely shared gender stereotypes that are representative of masculinity-femininity social dimensions (Bem, 1974). They include stereotypes about personality traits (e.g., males are meant to be independent, tough and assertive, and females are seen as emotional, sensitive and people-oriented), roles (e.g., males as a defender of the family and companion; females as nurtures and caregivers), and preferences (e.g., males more interested in watching sports, females more interested in shopping).

In the last few decades, many gender equity changes have taken place (Inglehart and Norris, 2003). Gender roles and traits for females and males are more flexible, and traditional archetypes for masculinity and femininity are no longer seen as bipolar dimensions (Choi \& Fuqua, 2003). Despite current changes, the gender variable is still an important aspect to understand human behavior. Not surprisingly, people are still using traditional gender schemata to built their own gender identity (López-Zafra \& López-Sáez, 2001), and gender schemata guide their individual preferences, knowledge, memory and behavioral interactions with others (Giles \& Heyman, 2005; Ridgeway $\&$ Correll, 2004). Indeed gender has been defined as socially inferred information from which observers not only form their judgments about others, but also choose their own conduct (Deaux \& Lewis, 1984).

Psychological research has suggested that gender stereotypes are developed in infancy through both direct experiences and mass media images (Matud, Rodríguez \& Espinosa, 2011). Knowledge of these stereotypes may greatly influence children's comprehension of the world, and also the way they relate with other people and social objects. Spanish research that analyzes children's knowledge of gender stereotypes is scarce and such information would be very interesting. On the one hand, this article offers a review of the research carried out on children's gender stereotypes in relation to preferences. On the other hand, it offers guidelines for future research in Spain, and also for other countries, where studies into children's development of gender stereotypes is limited.

\section{Gender development: theoretical framework}

Gender studies have attempted to understand how individuals acquire a set of preferences, behaviors, interests, skills, and even personality traits, which are more typical of their own sex. Acquisition of these features has been called the gender-typing process and the two most relevant theories that analyze such processes are: the Social Learning Theory and the self-social- ization theories. Researchers who analyze gender-typed preferences must ensure that the theory underlying each variable examined in the study is discussed and contextualized.

\section{The Social Learning Theory of gender development}

This theory considers that gender-typed preferences are learnt from socialization agents (family, teachers, etc.) that reinforce the social expected behaviors for each gender and provide negative consequences if boys or girls reproduce preferences that are more appropriate for the opposite gender (Bussey and Bandura, 1999, Campbell et al. 2002). From this perspective, boys and girls are exposed to different socialization pressures from birth which create differences when providing specific names, toys, clothes and bedroom furniture to distinguish between girls' and boys' gender-appropriate objects (Bandura, 1977). For example in color preferences terms, the study by Boyatzis and Varghuese (1994) suggested that children's color preferences can be the result of their early socialization experiences. When the authors asked US children aged between 4-7 years about their favorite color, girls explained they thought that pink was a happy color because they had lots of pink dresses. Boys liked black because they associated it with their own sportswear. Recent research has also shown the importance of parent-child socialization practices and the gender context of adulthood in understanding children's color preferences (Cohen, 2013).

However, since the 1960s, the Social Learning Theory sees boys and girls not only as mere receptors of the reinforcement of socialization agents, but also their adoption of the preferences and behaviors of the male and female model, which they observe and imitate. Children may learn behaviors that are reinforced for each gender from people who are close to them, but also from mass media models. From this perspective, gendertyped preferences may emerge by observing the contingences that other kids experience after their behavior. For instance, if a boy observes that another boy who plays with dolls is punished by peers or parents, he may think that this behavior is not adequate for his own gender. The fact that children learn through vicarious processes evidences that cognitive schemata need to be included in the theory (Bandura \& Bussey, 2004).

\section{Self-socialization theories of gender development}

From this perspective, both sexes actively seek genderrelated information which will serve as a guide for their own conduct, and will contribute to their own socialization (Halim, Ruble, Tamis-LeMonda \& Shrout, 2013; Martin \& Ruble, 2004). For example, gender-typed color preferences may be the result of observing the preferences that others have. Boys' avoidance of pink and purple might be related with the observation that girls wear clothes and accessories in these colors, and boys may think that wearing these colors is not suitable for their gender (Chiu, Gervan, Fairbrother, Johnson \& OwenAnderson, 2006). 
The self-socialization perspective is not incompatible with the Social Learning Theory. Indeed, the latter theory has been reformulated to include a cognitive perspective (Bussey \& Bandura, 1999) after the understanding that children can search, select and remember social information that is consistent with their own gender schemata, and they can ignore, reject or forget inconsistent information (Bandura \& Bussey, 2004). Although the Self-Socialization Theory accepts that socialization can contribute to develop gender-related schemata, it does not affirm that these schemata are always consistent with social gender stereotypes. In this process, children are active as they seek information that may, or may not, be congruent with gender stereotypes depending on the individual, the social context, and on other conditions that make gender a salient variable, such as peer pressure (Halim, Ruble, Tamis-LeMonda, Zosuls, Lurye, Greulich, 2014; Martin \& Ruble, 2010).

In summary, both theories suggest the possibility there may be differences in children's gender-related preferences and behaviors in accordance with gender stereotypes.

\section{Gender-typed preferences: an overview of international research}

A large body of research conducted across various cultural contexts evidences that children demonstrate gender-stereotyped activities preferences. This overview of international studies aims to: generate a debate of the state of gender research on gender-typed children preferences; help understand that we cannot assume that universal gender mechanisms govern gender-typed preferences; and help comprehend that the results of any empirical study are not independent of culture. An examination of these studies may not only be informative for gender researchers, but may also identify directions for future research in Spain and in other countries.

\section{Research on gender-typed objects preferences}

Research has documented the existence of gender-typed toy preferences as early as 18 months of age, with girls looking significantly more at dolls and boys contemplating cars more (Jadva, Hines \& Golombok, 2010). Children's gender-typed preferences for toys grow larger with development (Golombok \& Hines, 2002); studies conducted in the US (Goldberg, Kashy \& Smith, 2012), Sweden (Nelson, 2005) or the UK (Dunn \& Hughes, 2001) have reported consistent patterns, indicating that girls prefer dolls, stuffed animals and educational toys, whereas boys prefer vehicles, action figures, tool sets or construction toys. In addition to differences in preferences, boys and girls show a stronger bias for toys stereotyped as own-gender than for cross-gender-typed or gender-neutral toys (Cherney, KellyVance, Gill, Ruane \& Ryalls, 2003). However, this bias is stronger for boys. Although the age when children show a preference for own-gender or cross-gender toys varies across studies, American (Cherney \& London, 2006) and Swedish (Servin, Nordenström, Larsson \& Bohlin, 2003) boys aged between
2-13 play essentially with masculine toys, whereas girls play more with feminine toys, although girls often choose to play with neutral toys and masculine toys.

Toys are also gender-stereotyped in color terms. Auster and Mansbach (2012) analyzed the gender marketing of toys on the US Disney Store web site to find that action figures, building toys, weapons or small vehicles were colored predominantly red, black, brown or gray, and were classified as masculine toys. Dolls, beauty, cosmetics, jewelry or domestic-oriented toys were colored mainly pink or purple. As we mentioned earlier, these colors are differentially preferred by girls and boys as a product of gender socialization, and learning these gender cues may lead children to not only associate objects with one gender or another, but to make choices based on these cues. Color seems to guide children's choices when they have to choose among items or toys stereotyped as own-gender. However, color is less important when it comes into conflict with other gender stereotypes. For example, if girls and boys have to choose among two items, one stereotyped as own-gender in pink (female stereotyped color) and other item stereotyped as cross-gender in blue (male stereotyped color), their choices are usually guided by their gender-associated item, and not by stereotyped color (Karniol, 2011).

More recently in two studies, Weisgram, Fulcher and Dinella (2014) explored the roles of explicit gender labels (toys "for boys", toys "for girls") and gender-typed colors on preschool children preferences for toys in the United States. In these studies, children were presented with masculine toys (e.g., construction toys, monster trucks) and feminine toys (e.g., tea sets, ponies) that were decorated with masculine and feminine colors. They had two of each toy, of which one was altered by hand painting it the colors associated with the opposite gender (e.g., the color scheme of the pony was altered by hand painting it with black and blue acrylic paint, and the pink mane and tail were replaced with black hair). Both studies demonstrated that children were more interested in the familiar toys associated with their gender, and in the novel toys labeled for their gender than in the toys not associated with or labeled as their gender. However, color was found to be only a salient construct among girls. Feminine colors significantly increased girls' personal interest in masculine toys or toys labeled for boys, and also the likelihood of these items being categorized as "for girls" increased. They concluded that pink gives girls permission to venture into the masculine toy domain as it increases the their sense of belonging to those items. However, the color of the toys had little effect on boys' interests. Boys were not interested in feminine toys when depicted with masculine colors. Once again, it seemed that boys are not willing to cross the gender barrier into girls' domains because gender roles for boys seem more rigid than those for girls.

Regarding the development of gender-typed preferences, the literature posits that after the age of 3 , boys and girls tend to use a larger number of gender cues. It also indicates that they 
possess knowledge of their own gender by responding to stereotypes in relation to choosing not only certain toys, but also certain stereotypes. This marks differences in boys' and girls' appearance (e.g., how they dress), as well as their preference for activities (e.g., boys play sports and girls dance). At about the age of 5, children know more gender stereotypes, including more abstract stereotypes as social roles. At about the age of 5-7 years, children generally show greater rigidity to adhering to gender stereotypes, and girls and boys gradually show greater flexibility in adhering to these stereotypes after the age of 8 (Leaper \& Friedman, 2007; Ruble, Martin \& Berenbaum, 2006). However, very few studies have been conducted on the continuity of gender-typed preferences from early childhood to adolescence. One exception is the study conducted by Golombok, Rust, Zervoullis, Golding and Hines (2012), which examined the continuity of gender-typed behavior from preschool (age 3) to adolescent years (age 13). It was found that the degree of gender-typed behavior shown by preschool children is a good indicator of their degree of gender-typed behavior following the transition to adolescence. The girls who had been masculine at the age of 3 displayed greater self-efficacy for male-typed activities than average girls aged 13, while the girls who had been feminine at the age of 3 exhibited greater self-efficacy for female-typed activities. In the same way, the boys who had been feminine at 3 showed lesser self-efficacy for female-typed activities than average boys aged 13, and the boys who had been masculine at 3 felt more competent in maletyped activities. It appears, therefore, that the degree to which children show gender-typed behavior at 3 is indicative of their future level of gender-typed behavior.

\section{Research into gender-typed color preferences}

Research shows that gender differences in color preferences become clearer as of the age of 3. To support this view, Jadva, Hines and Golombok (2010) examined preferences for different toys, colors and shapes in 120 UK infants aged 12, 18 and 24 months. Although they found that girls looked at dolls significantly more than boys did, and that boys looked at cars significantly more than girls did, they found no significant gender differences in infants' preferences for pink or reddish colors over blue until the age of 3 . These authors argued that sex differences in toy preferences may contribute to gender differences in preference for colors. For example, girls may learn to like pink because many toys they play with are pink.

International research has analyzed how children's color selections match cultural color gender stereotypes. In light of this, some studies have specifically found that girls pick pink and purple much more than boys (Chiu, et al., 2006). By the age of 3 , girls have developed a strong preference for pink objects, and boys display a marked rejection of pink-colored objects (LoBue \& DeLoache, 2011). When children choose toys for their peers' bedrooms, boys and girls pick pink-colored objects for girls' bedrooms and blue-colored ones for boys' bedrooms (Cunningham \& Macrae, 2011). Likewise, girls prefer violet, magenta or red for their clothes, while boys tend to choose black, blue or yellow (Kilinç, 2011).

Research has also found gender differences in children's use of color in their drawings. Milne and Greenway (1999) tested their use of color in the drawings of Australian students aged 4-14 years, and found that girls tend to use color more frequently in their drawings regardless of age. Ijima, Arisaka, Minamoto and Yasumasa (2001) examined drawings of 124 Japanese boys and 128 Japanese girls aged 5-6 years. They found that boys used significantly fewer colors in their free drawings than girls, and that the most usual colors employed by boys were gray and blue. Conversely, girls liked using a wider variety of colors and they normally chose "warmer" colors, including pink, compared to boys. Turgeon (2008) examined sex differences in the drawings produced by US children aged 5-9 years. She found that girls used a wider variety of colors, especially more pink and purples, than boys. Similarly, Karniol (2011) found that Israeli girls aged 4-8 years employed a wider variety of colors in a coloring activity than boys of the same age. Boys particularly avoided using pink and preferred malestereotyped colors (e.g., blue, green) than female-stereotyped colors (e.g., pink, purple) if compared to girls. Boys' avoidance of pink showed that "boys are reluctant to be associated with objects and colors that are female-stereotyped" (p.127).

Children's color activities are also influenced by the stereotyped nature of their drawings. Fitzpatrick and MacPherson (2010) analyzed coloring books in the USA and discovered that girls' coloring books contained mainly princesses, dolls or fairies, whereas boys' coloring books included action figures, weapons and vehicles. After considering the gender-stereotyped nature of coloring books, Karniol (2011) examined the stereotypes that Israeli children showed when choosing colors. She offered two gender stereotyped illustrations (a fairy and an action figure), and asked the children to color the figure with male and female stereotyped colors. She found that boys' use of female stereotyped color did not vary across figures and that they avoided coloring the fairy and using pink. Girls used more female stereotyped colors for the fairy and more male stereotyped colors for the action figures. Thus, the stereotyped nature of the illustration may influence children's use of color.

\section{Spanish research in gender-typed preferences}

Psychological studies on gender in Spain have been conducted in the last three decades (Barberá \& Cala, 2008). Indeed gender issues are nowadays a priority area in psychological research and cover different topics; namely, gender stereotypes, gender violence and equity at work (Gartzia \& López-Zafra, 2014). The importance that gender stereotypes have in interpersonal processes has been the focal point of the most important research groups in Spain. They have examined gender stereotypes as beliefs that play a determining role in social perceptions and expectations, self-concept development, and also in establishing social relationships (Echebarría \& Valencia, 1993). However, Spanish research into gender stereotypes has been 
conducted mostly with adolescents and adults, and has measured the perception that participants have about women's and men's characteristics (López-Sáez, Morales \& Lisbona, 2008).

Although there is a large body of research on gender stereotypes in adolescence and adulthood, far fewer works have been conducted on children's gender stereotypes. Research in this area has analyzed male and female stereotypes in different materials directly with children and preadolescents. The study by Manassero and Vázquez (2002) examined gender stereotypes in the language used in 32 secondary school science and technology textbooks. The goal was to evaluate the degree of gender equity in new textbooks, as set out in subsequent Spanish laws on education in 1996. The overall result for gender stereotypes reveals an unsatisfactory situation because the language employed in the examined textbooks did not respect gender equity tenets. However, they found some hopeful indicators of change in the gender stereotypes of male and female roles. Men and women were represented in the roles, activities and occupations traditionally associated with the opposite sex. The study by Espinar (2007) analyzed the transmission of women and men's stereotyped characteristics through advertisements in Spanish audiovisual contents for children in 2004. She concluded that children's advertisements reinforce traditional stereotypes about men and women. Girls' products are related with motherhood and aesthetics, while boys' products are related with physical activity or action games.

However, less is known about the gender-typed preferences and behaviors in childhood. To our knowledge, only two studies deals with gender stereotypes and their influence on children's preferences. First, the study of boys' and girls' gender-typed activities (Lobato, 2005) examining the behavior of 5-year-old children in their socio-dramatic role play. A series of 30 roleplay sessions were observed in a classroom and involved 16 students (10 boys and 6 girls). The sessions, involving different scenarios, were classified as female-dominated, male-dominated, or neutral. The results showed that significant differences in children's play behavior relate to their gender, and that these differences indicate stereotypes; that is, boys' scripts centered on action and aggression, whereas girls focused more on personal relationships, household settings, and caring for and attending other people. Differential behaviors were maintained throughout the diverse role-play scenarios. She concluded that gender differences appear in role play in early childhood years. Second, the study of boys' and girls' gender-typed toy preferences (Martínez \& Velez, 2009) which included 400 children aged between 3-7 years. They were asked which items on a list of 35 toys (12 stereotypically associated with males, 12 with female, and 11 generally considered neutral) were "boys only", "girls only" or "both boys and girls". The aim was to examine if children tended to associate toys with one gender or another, and whether this relationship was related to gender stereotypes. The results revealed that 3-year-old children perceive toys in neutral ways (toys were normally considered appropriate for "both boy and girls"). However, gender differentiation of toys becomes increasingly evident after the age of 4 . Of all 35 toys tested, only three were recognized mostly as neutral (a building game, a briefcase with medical instruments, and a computer). However $89 \%$ of the children's responses indicated that Playstation is considered a "boys only" toy. One interesting result was that no toy was considered neutral by more than $50 \%$ of respondents, while 22 of the 35 toys were identified mostly as being more appropriate for only one sex, according to $75 \%$ of the responses.

In other Spanish-speaking countries, the situation of researching children's gender stereotypes is similar to that described above for Spain. Latin American research, which has analyzed representations of both men and women in different mass media types, has shown that girls and boys are still exposed to traditional gender stereotypes in countries like Argentina (Plaza, 2009), Chile (Barrios, 2011), Colombia (López de la Roche, 2000), or México (Luevano, 2013). Studies which asked children about their gender-related preferences have found that boys and girls still hold gender stereotypes. For example, Chaves (2005) conducted an observational study with preschool children in Costa Rica. She found that boys and girls exhibited gendered behaviors, attitudes and choices. Specifically, the children's dramatization play in the classroom differed according to gender. Girls acted more as nurtures, housewives and went shopping. Boys acted as doctors, handymen and constructors. Jiménez, Inzuna, Amor and Guajardo (2013) analyzed children's gender roles among Mexican boys and girls aged 10-12 years. They found that children showed gender-typed preferences, where girls liked dancing and boys liked sports.

These studies indicate that gender influences Spanish and Latin American children's attitudes to objects and people. Yet despite the existence of several studies, studies into genderrelated preferences (e.g., toys and colors) during childhood are still important to help gain a more nuanced understanding of how gender develops in different countries. Future research should take full advantage of the studies conducted in the other countries reviewed below and address different aspects that would be interesting for the advance of gender research in Spanish-speaking countries and for the understanding of the impact that gender beliefs have on children. These aspects can be summarized as follow: 1) Examine gender-typed preferences in preschool-age populations, and even younger samples since research has shown that, for example, visual preferences for gender-typed toys begin as toddlers (Jadva et al., 2010); 2) Analyze the intentional marketing of toys that use gender labels and color labels, and how these labels may serve to increase children gender stereotypes and to also intensify gender differences in many areas of development (e.g., interests, abilities or even desired occupations); 3) Conduct longitudinal studies to understand the formation of children gender schemas and the continuity of gender-typed preferences from childhood to 
adolescence. These studies will allow us to test the theoretical explanations of the processes involved in children's acquisition of gender-typed preferences that derive from social learning and self-socialization theories. Thus it will be important to examine how one kind of gender-typing at one age relates to a different kind at a later age (Martin \& Ruble, 2010). Does interest in baby dolls predict later interest in desired occupations (e.g., teacher)? Future research should provide answers to such questions. 4) Considering the relative gender progress in the Spanish society over the last decades, it will be important to analyze contemporary parental practices to encourage gender typical and atypical behaviors, and how these different practices influence gender-typed preferences. These studies will allow us to analyze how social influences are related with the formation of children gender schemas, as argued from social learning theories. 5) By moving forward preferences for different toys, studies should also analyze how gender-typed preferences influence their interest in other objects; e.g., clothes. Future research should analyze the gender cues that children use to classify the clothes that can be worn by both genders; e.g., shoes, T-shirts, jerseys, etc., and gender-typed colors can be central in this process. As Martin and Ruble (2010) stated, how children apply stereotypes once they have learned them is an issue of continued interest in the field.

\section{Conclusion and recommendations for future research}

The findings reported in the above reviewed studies reveal that children's preferences of toys and colors are quite gendered, and that particular objects and colors are strongly associated with gender. However, as we noticed before, we cannot assume that the results of any empirical study represent universal truths independently of culture. This review evidences that very few cross-cultural studies on children gender-typed preferences are available. Furthermore, as far as we know, no comparative studies have been done between cultures to replicate previous findings that used the same methodological procedure.

If researchers wish to bridge this gap in gender research, and if they want to contribute to the international debate that derives from other countries' research, replicas of previous studies are needed if research into gender-related preferences pretends to understand how gender affects children perceptions and activities and identities formation. In an attempt to fulfill this goal, researchers should consider the following recommendations, which stem from the present review:

\section{Theory related to empirical data}

Researchers should explain the theory that their study is supported on. It is important that studies will be designed to test competing hypothesis about explanations from theories on gender development involving social influences or cognitive development. However, researchers have to consider that gender-typing may vary as a result of different combinations of biological, cognitive and social processes (Martín and Ruble, 2004). The Social Learning Theory and self-socialization theories do not allow the understanding of development of gendertyped behaviors in every phase of life. For example, some gender-typed behaviors (e.g., toy preferences) emerge prior to the age of 2, when identification with gender as a social category is still in construction. In this case, social influences and gender understanding may play a less important role in gender-typing. We also have to consider that social influences may be affected by biological disposition. For example, girls exposed to high levels of androgenic hormones prior to birth show predisposition to gender-atypical play, and this predisposition seems persistent, despite parental effort to encourage gender-typical behaviors (Paterski, Geffner, Brain, Hindmarsh, Brook, \& Hines, 2005). In this way, research predictions should be cautiously made after considering the possible intercorrelations among biological, cognitive and social processes.

\section{Need for replicas}

The majority of studies have been conducted in the US and the UK, and they have found similar patterns. However, we cannot attempt to generalize about Western culture. Replication in Western and Eastern countries will help gain a better understanding of how gender operates on children preferences when making decisions about gender-type objects, and can also help identify cross-cultural differences. Future studies should include a section that discusses the characteristics of the culture according to which the study is conducted and how we can expect different findings than those found in previous research.

\section{Inclusion of new variables}

There are many types of influences on how children gendertyped preferences develop. For example, Goldberg, Kashy and Smith (2012) examined whether young children's gender-type play varied according to the family structure. These authors found that children of lesbian mothers demonstrated less gender-typed play behaviors than children of heterosexual parents. This finding reveals the importance of examining gender-typed preferences in multiple settings and different family types and also analyzing different socialization pressures regarding gender.

\section{Methodological issues}

One limitation of the some of the above studies reviewed is classroom participant work together with classmates (e.g., Karniol 2011), which means that the task can be influenced by what other children do (peer pressures). For further studies, tasks outside the classroom can be done on an individual basis. Observational studies, rather than paper-and-pencil measures, may also provide a better methodology to examine gender typing in childhood. When children become older, they are able to better explain why they prefer some toys, activities or colors. Experimental and correlational studies would be 
also enriched if they employed personal interviews or focus groups in which boys and girls can explain the decisions they make.

\section{Age range of samples}

Research has shown that beyond the age of 8 , girls and boys show greater flexibility in adhering gender stereotypes because their social experiences are more varied (Leaper \& Friedman, 2007). Indeed the fact that older children are able to identify stereotypes does not necessarily imply that they personally endorse such generalizations (Liben \& Bigler, 2002). So we may think that older children's preferences are less influenced by gender stereotypes than the choices made by younger children. However, recent research has shown that those children who show a gender-typed behavior at the age of 3 still show a gender-typed behavior at 13 (Golombok et al., 2012). Future research shoul examine these trends extending the age range of their sample in order to understand the development of gendertyped preferences, and if they operate independently of children's degree of gender stereotyping.

\section{References}

1. Auster, C.J. \& Mansbach, C.S. (2012). The gender marketing of toys: an analysis of color and type of toy on the Disney Store Website. Sex Roles, 67, 375-388. http://dx.doi. org/10.1007/s11199-012-0177-8

2. Bandura, A. (1977). Social learning theory. London: Prentice Hall.

3. Bandura, A. \& Bussey, K. (2004). On broadening the cognitive, motivational, and sociostructural scope of theorizing about gender development and functioning: Comment on Martin, Ruble, and Szkrybalo (2002). Psychological Bulletin, 130, 691-701. http://dx.doi.org/10.1037/00332909.130.5.691

4. Barberá Heredia, E. \& Cala Carrillo, M. J. (2008). Perspectiva de género en la psicología académica española. Psicothema, 20, 236-242.

5. Barrios, L. A. (2011). La mujer en la televisión: el caso chileno. Cuadernos de Información, 29, 105-116.

6. Bem, S. L. (1974). The measurement of psychological androgyny. Journal of Consulting and Clinical Psychology, 42, 155-162. http://dx.doi.org/10.1037/h0036215

7. Boyatzis, C. J. \& Varghese, R. (1994). Children's emotional associations with colors. The Journal of Genetic Psychology, 155, 77-85. http://dx.doi.org/10.1080/00221325.1994 .9914760

8. Bussey, K. \& Bandura, A. (1999). Social cognitive theory of gender development and differentiation. Psychological review, 106, 676-713. http://dx.doi.org/10.1037//0033295X.106.4.676

9. Campbell, A., Shirley, L. \& Caygill, L. (2002). Sex-typed preferences in three domains: Do two-year-olds need cognitive variables? British Journal of Psychology, 93, 203217. http://dx.doi.org/10.1348/000712602162544
10. Chaves, A.L (2005). Las relaciones de género en el contexto escolar. Un estudio de caso a nivel de educación escolar. Diálogos, 5 (1-2). Retrieved from: http://www.redalyc. org/articulo.oa? $\mathrm{id}=43926968022$

11. Cherney, I. D. \& London, K. (2006). Gender-linked differences in the toys, television shows, computer games, and outdoor activities of 5-to 13-year-old children. Sex Roles, 54, 717-726. http://dx.doi.org/10.1007/s11199-0069037-8

12. Cherney, I. D., Kelly-Vance, L., Gill, K., Ruane, A. \& Ryalls, B. O. (2003). The effects of stereotyped toys and gender on play-based assessment in 18-48 months old children. Educational Psychology, 23, 95-106. http://dx.doi. org $/ 10.1080 / 01443410303222$

13. Chiu, S. W., Gervan, S., Fairbrother, C., Johnson, L. L., Owen-Anderson, A. F. H., Bradley, S. J. \& Zucker, K. J. (2006). Sex-dimorphic color preference in children with gender identity disorder: A comparison to clinical and community controls. Sex Roles, 55, 385-395. http://dx.doi. org/10.1007/s11199-006-9089-9

14. Choi, N. \& Fuqua, D.R. (2003). The structure of the Bem Sex Role Inventory: A summary report of 23 validation studies. Educational and Psychological Measurement, 63, 872-887. http://dx.doi.org/10.1177/0013164403258235

15. Cohen, P. N. (2013). Children's gender and parents' color preferences. Archives of sexual behavior, 42, 393-397. http://dx.doi.org/10.1007/s10508-012-9951-5

16. Cunningham, S.J. \& Macrae, C.N. (2011). The colour of gender stereotyping. British Journal of Psychology, 102, 598-614. http://dx.doi.org/10.1111/j.20448295.2011.02023.x

17. Deaux, K. \& Lewis, L. (1984). Structure of gender stereotypes: Interrelationships among components and gender label. Journal of Personality and Social Psychology, 46, 991-1004. http://dx.doi.org/10.1037//0022-3514.46.5.991

18. Dunn, J. \& Hughes, C. (2001). "I Got Some Swords and You're Dead!": Violent Fantasy, Antisocial Behavior, Friendship, and Moral Sensibility in Young Children. Child Development, 72, 491-505. http://dx.doi.org/10.1111/1467$\underline{8624.00292}$

19. Echevarría, A., Garate, V. \& Francisco, J. (1993). Identidad de género, ética protestante y atribución de causalidad. Revista de Psicología Social, 8, 235-247. http:// dx.doi.org/10.1080/02134748.1993.10821682

20. Espinar Ruiz, E. (2007). Estereotipos de género en los contenidos audiovisuales infantiles. Comunicar, 29, 129-134.

21. Fitzpatrick, M. J. \& McPherson, B. J. (2010). Coloring within the lines: Gender stereotypes in contemporary coloring books. Sex roles, 62, 127-137. http://dx.doi. org/10.1007/s11199-009-9703-8

22. Gartzia, L. \& Lopez-Zafra, E. (2014). Gender Research in Spanish Psychology: An Overview for International Readers. Sex Roles, 70, 445-456. http://dx.doi.org/10.1007/ s11199-014-0380-x 
23. Giles, J.W. \& Heyman, G.D. (2005) Young children's beliefs about the relationship between gender and aggressive behavior. Child Development, 76, 107-121. http:// dx.doi.org/10.1111/j.1467-8624.2005.00833.x

24. Goldberg, A. E., Kashy, D. A. \& Smith, J. Z. (2012). Gender-typed play behavior in early childhood: Adopted children with lesbian, gay, and heterosexual parents. Sex roles, 67, 503-515. http://dx.doi.org/10.1007/s11199-0120198-3

25. Golombok, S. \& Hines, M. (2002). Sex differences in social behavior. In P.K. Smith \& C.H. Hart (Eds.), Blackwell handbook of childhood social development (pp. 117-136). Malden, MA: Blackwell Publishing.

26. Golombok, S., Rust, J., Zervoulis, K., Golding, J. \& Hines, M. (2012). Continuity in sex-typed behavior from preschool to adolescence: A longitudinal population study of boys and girls aged 3-13 years. Archives of sexual behavior, 41, 591597. http://dx.doi.org/10.1007/s10508-011-9784-7

27. Halim, M. L., Ruble, D., Tamis-LeMonda, C. \& Shrout, P. E. (2013). Rigidity in gender-typed behaviors in early childhood: A longitudinal study of ethnic minority children. Child development, 84, 1269-1284. http://dx.doi. org $/ 10.1111 /$ cdev. 12057

28. Halim, M. L., Ruble, D. N., Tamis-LeMonda, C. S., Zosuls, K. M., Lurye, L. E. \& Greulich, F. K. (2014). Pink frilly dresses and the avoidance of all things "girly": Children's appearance rigidity and cognitive theories of gender development. Developmental psychology, 50, 1091-1101. http:// dx.doi.org/10.1111/cdev.12057

29. Iijima, M., Arisaka, O., Minamoto, F. \& Arai, Y. (2001). Sex differences in children's free drawings: a study on girls with congenital adrenal hyperplasia. Hormones and Behavior, 40, 99-104. http://dx.doi.org/10.1006/hbeh.2001.1670

30. Inglehart, R. \& Norris, P. (2003). Rising tide: Gender equality and cultural change around the world. Cambridge: Cambridge University Press. http://dx.doi.org/10.1017/ CBO9780511550362

31. Jadva, V., Hines, M. \& Golombok, S. (2010). Infants' preferences for toys, colors, and shapes: sex differences and similarities. Archives of sexual behavior, 39, 1261-1273. http://dx.doi.org/10.1007/s10508-010-9618-Z

32. Jiménez, D., Inzuna, A., Amor, F. \& Guajardo, J (2013). El género en la niñez: percepción de género en niños y niñas de primaria superior en Monterrey. Intersticios, Revista sociológica de pensamiento crítico, 7, 273-293.

33. Karniol, R. (2011). The color of children's gender stereotypes. Sex Roles, 65, 119-132. http://dx.doi.org/10.1007/ s11199-011-9989-1

34. Kilinç, N. (2011). Clothing color preferences of boys and girls aged between six and nine. Social Behavior and Personality, 39, 1359-1366. http://dx.doi.org/10.2224/ sbp.2011.39.10.1359

35. Leaper, C. \& Friedman, C.K. (2007). The socialization of gender. En J.E. Grusec \& P. D. Hastings (Eds.), Handbook of socialization: theory and research. (pp. 561-587) New York: Guilford Publications.

36. Liben, L.S. \& Bigler, R.S. (2002). Extending the study of gender differentiation: reply. Monographs of the society for research in child development, 67, 179-183. http://dx.doi. org/10.1111/1540-5834.00203

37. Lobato, E. (2005). Juego sociodramático y esquemas de género. Una investigación en educación infantil. Cultura y Educación, 17, 115-129. http://dx.doi. org/10.1174/1135640054192847

38. LoBue, V. \& DeLoache, J.S. (2011). Pretty in pink: the early development of gender-stereotyped colour preferences. British Journal of Developmental Psychology, 29, 656-667. http://dx.doi.org/10.1111/j.2044-835X.2011.02027.x

39. López de la Roche, M (2000). Los niños como audiencia: investigación sobre recepción de medios. Bogotá: Da Vina Editores y Cía.

40. López-Sáez, M., Morales, J.F. \& Lisbona, A. (2008). Evolution of gender stereotypes in Spain: traits and roles. The Spanish Journal of Psychology, 11, 609-617.

41. López-Zafra, E. \& López-Sáez, M. (2001). Por qué las mujeres se consideran más o menos femeninas y los hombres más o menos masculinos. Explicaciones sobre su autoconcepto e identidad de género. Revista de Psicología Social, 16, 193-207. http://dx.doi.org/10.1174/021347401317351134

42. Luevano, H.A. (2013). El diseño del empaque del juguete y su relación con los estereotipos de género. Revista digital universitaria, 14, 2-12. Retrieved from: http://www.revista. unam.mx/vol.14/num7/art17/index.html.

43. Manassero, M. A. \& Vázquez, A. (2002). Los estereotipos de género y el lenguaje en los libros de texto de ciencias. Cultura y educación, 14, 415-429. http://dx.doi. org/10.1174/113564002762700880

44. Martin, C.L. \& Ruble, D.N. (2004). Children's search for gender cues: cognitive perspectives on gender development. Current directions in psychosocial science, 13, 67-70. http://dx.doi.org/10.1111/j.0963-7214.2004.00276.x

45. Martin, C.L. \& Ruble, D.N. (2010). Patterns of gender development. Annual Review of Psychology, 61, 353-381. http://dx.doi.org/10.1146/annurev.psych.093008.100511

46. Martínez, M.C. \& Vélez, M. (2009). Actitud en niños y adultos sobre los estereotipos de género en juguetes infantiles. Ciencia Ergo Sum, 16, 137-144.

47. Matud, M. P. (2004). Género. En M. P. Matud, R.J. Marrero \& M. Carballeira (Coords). Psicología diferencial (pp. 151178), Madrid: Biblioteca Nueva.

48. Milne, L.C. \& Greenway, P. (1999). Color in children's drawings: the influence of age and gender. The Arts in Psychotherapy, 26, 261-263. http://dx.doi.org/10.1016/S01974556(98)00075-6

49. Moya, M.C. (1996). Identidad social y relaciones interpersonales. En J.F. Morales, D. Páez, J.C. Deschamps \& S. 
Worchel (Eds), Identidad Social. Aproximaciones psicosociales a los grupos y a las relaciones entre los grupos (pp.423-438), Valencia: Promolibro.

50. Nelson, A. (2005). Children's toy collections in Swedena less gender-typed country? Sex roles, 52, 93-102. http:// dx.doi.org/10.1007/s11199-005-1196-5

51. Pasterski, V.L., Geffner, M.E., Brain, C., Hindmarsh, P., Brook, C. \& Hines, M. (2005) Prenatal hormones and postnatal socialization by parents as determinants of male-typical toy play in girls with congenital adrenal hyperplasia. Child Development, 76, 264-278. http://dx.doi.org/10.1111/ j.1467-8624.2005.00843.x

52. Plaza, J. F. (2009). La globalización de la identidad de género en las revistas para las adolescentes. Zer-Revista de Estudios de Comunicación, 14, 129-144.

53. Ridgeway, C. \& Correll, S.J. (2004). Unpacking the Gender System: A Theoretical Perspective on Cultural Beliefs and Social Relations. Gender and Society, 18, 510-531. http:// dx.doi.org/10.1177/0891243204265269

54. Ruble, D.N., Martin, C.L. \& Berenbaum, S. (2006). Gender development. In . W. Damon, R.M. Lerner \& N. Eisenberg (Eds.), Handbook of child psychology: Vol.3, Social Emotional and personality development (pp. 858-932). New York: Wiley.
55. Servin, A., Nordenström, A., Larsson, A., \& Bohlin, G. (2003). Prenatal androgens and gender-typed behavior: A study of girls with mild and severe forms of congenital adrenal hyperplasia. Developmental Psychology, 39, 440450. http://dx.doi.org/10.1037/0012-1649.39.3.440

56. Turgeon, S.M. (2008). Sex differences in children's free drawings and their relationship to 2D:4D ratio. Personality and Individual Differences, 45, 527-532. http://dx.doi. org/10.1016/j.paid.2008.06.006

57. Weisgram, E. S., Fulcher, M., \& Dinella, L. M. (2014). Pink gives girls permission: Exploring the roles of explicit gender labels and gender-typed colors on preschool children's toy preferences. Journal of Applied Developmental Psychology, 35, 401-409. http://dx.doi.org/10.1016/j. appdev.2014.06.004

Received 6 June 2014 Received in revised form 17 October 2014 Accepted 22 October 2014 